\title{
Corporate Social Responsibility and MNCs: An Appraisal from Investment Treaty Law Perspective
}

\author{
Shamila Dawood* \\ University of Colombo, Sri Lanka
}

\begin{abstract}
Recent investment treaties recognize corporate social responsibility (CSR) as a mechanism for regulating corporate behavior concerning the protection and promotion of human rights, social and environmental standards. These treaties often include a universally recognized soft law version of CSR developed by the International Labor Organization (ILO) and the Organization for Economic Co-operation and Development (OECD), considered prominent sources of CSR voluntary standards. This study analyzed significant advances in including such voluntary standards in investment treaty law, which led to implementing globally agreed norms regarding sustainable development into action. In addition to the inclusion of CSR standards in legally binding documents, this study argued that the practical issues involved in implementing the CSR standards should be addressed from the perspective of capitaldependent developing countries. To this end, this study adopted the due diligence test to apply CSR standards in cross-border investments better. For this purpose, theoretical analysis that combined descriptive and analytical approaches based on the available primary and secondary sources best suited current research. The study showed that applying CSR standards in capitaldependent developing countries was only possible when corporate, home state, and the host government took appropriate actions at the policy level. It concluded that such additional measures were needed to effectively implement CSR standards emphasizing prevention was better than cure and ensuring the appropriate due diligence process by the relevant parties.
\end{abstract}

KEYWORDS: Corporate Social Responsibility, Investment Laws, Developing Countries.

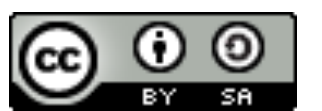

Copyright $\odot 2021$ by Author(s)

This work is licensed under a Creative Commons Attribution-ShareAlike 4.0 International License. All writings published in this journal are personal views of the authors and do not represent the views of this journal and the author's affiliated institutions.

HOW TO CITE:

Dawood, Shamila, "Corporate Social Responsibility and MNCs: An Appraisal from Investment Treaty Law Perspective" (2021) 2:2 Indonesian Journal of Law and Society 197-234, online: <https://doi.org/ 10.19184/ijls.v2i2.24262>.

Submitted: 10/05/2021 Reviewed: 11/05/2021 Revised: 13/08/2021 Accepted: 19/09/2021

*Corresponding authors' e-mail: dlfshamila@gmail.com 


\section{INTRODUCTION}

MNCs are the main actors in foreign direct investment. They can influence the future, drive innovation, develop technology, uphold corporate social responsibility (CSR), and reshape policy to suit their priorities and capabilities. ${ }^{1}$ In addition, CSR connects sustainability and development. For instance, the 2030 Agenda is a powerful framework to encourage businesses to implement CSR. ${ }^{2}$ In terms of foreign direct investment, CSR lays down procedures for MNCs to follow and provides guidelines to be followed by host states, home states, and civil society, in line with sustainable development. At the same time, strong wording of the CSR clause in an investment treaty and breach of such standard may increase liability. Dubin elaborates on the direct and indirect versions of CSR in investment agreements and argues that although direct CSR clauses are ambiguous, they are useful to the host country to use when resolving conflict with foreign investors. ${ }^{3}$ For developing countries, foreign investment is a significant source of economic growth. It is unlikely to go against MNCs' initiatives or bring in unfriendly foreign investment laws. Consequently, the object of the CSR clause should not only be considered a defensive mechanism but also to ensure best practice in doing businessmore precisely to ensure prevention is better than cure.

In this case, the implementation is significant, and it is the overall effort of the host state, home state, and MNCs. Then, this study provides a

1 UNCTAD, World Investment Report 2017: Investment and The Digital Economy (Geneva, 2017); World Bank, World Development Report 2017: Governance and The Law (Washington, 2017); Andrew Dearing, Sustainable Innovation: Drivers and Barriers (Geneva: OECD, 2000).

2 Most CSR standards are developed by non-state actors such as the United Nations, International Labor Organization (ILO), and OECD. Many MNCs, MNEs, and TNCs have pledged to adopt the voluntary codes developed by international organizations. Many have revised their internal policies to comply with the principles of these codes. See generally Sean D Murphy, "Taking Multinational Corporate Codes of Conduct to the Next Level" (2005) 43:2 Columbia Journal of Transnational Law 1-25.

3 Laurence Dubin, "Corporate Social Responsibility Clauses in Investment Treaties Investment Treaty News” (2018) Investment Treaty News, online: <https://www. iisd.org/itn/en/2018/12/21/corporate-social-responsibility-clauses-in-investmenttreaties-laurence-dubin/>. 
comprehensive analysis of CSR obligation as a mandatory requirement to adhere to responsible business practices and the effective roles of host, home state, and MNCs in ensuring human rights and environment protection from the point of capital dependent developing countries. Accordingly, it presents a series of non-binding instruments universally recognized as voluntary CSR standards, ${ }^{4}$ and argues, to a certain extent, the voluntary CSR standards influence investment communities and impact development in diverse ways, producing an array of possibilities and challenges. ${ }^{5}$ The initial version of the CSR standards was primarily concerned with labor issues; however, CSR standards now include social, environmental, and human rights aspects to protect against unhealthy investment practices. Nevertheless, voluntary mechanisms are not as beneficial to capital-dependent developing countries as touted. The promotion of responsible investment depends on how far companies pledge to implement voluntary standards in binding agreements. Few countries managed to inculcate such laws in domestic foreign investment law, BITs, and investment contracts instead of just internal company policies.

This study aimed to analyze the CSR clause in investment treaties and its practical application in capital-dependent states. The first part analyzes and compares the current CSR voluntary standards developed by international institutions. The second part analyzes the role of MNC as a critical player in foreign investment in improving human rights values, social and environmental protection, with the following position of capital-dependent developing host countries in regulating the behavior of MNCs. Finally, the study examines the implementation of CSR standards embedded in foreign investment laws. It adopts a due diligence test and analyzes from the corporate, host state, and home state perspectives.

4 IAWG, Promoting Standards for Responsible Investment in Value Chains (2011). United Nations, The Guiding Principles on Business and Human Rights: Implementing the United Nations "Protect, Respect and Remedy" Framework (Geneva: Publishing Service, 2011).

5 Ibid. 


\section{METHODS}

Given the nature of the research, an in-depth analysis covering the laws and attitudes of the key actors of foreign investment was required, namely, the host state, home state, and MNCs. For this purpose, theoretical analysis that combined descriptive and analytical approaches based on the available primary and secondary sources best suited current research. The data was collected through an extensive literature survey, library research, and internet search. While emphasizing the overall efforts of actors in preventing human rights and environmental impacts, the author used comparative legal analysis to recommend the effective implementation of CSR standards as a mandatory requirement. To this end, the author relied on soft laws, investment treaties between countries, statutes, reports, databases, and various government and non-government documents.

\section{AN OVERVIEW OF CSR VOLUNTARY STANDARDS}

The concept of CSR emerged to regulate the behavior of companies by considering the social, human rights, and environmental aspects of development in their ethics or codes of conduct and, ideally, to make legally binding commitments. Christian Aid defines CSR as 'an entirely voluntary, corporate-driven initiative to promote self-regulation as a substitute for regulation at either the national or international level.' ${ }^{6}$ Though companies form their business ethics, the concept of CSR has come under broad and intense study in recent years due to the increased awareness of sustainable development norms. In 1980, the UN brought out the International Code of Conduct on Transnational Corporations (UNCTC), ${ }^{7}$ but it was never approved. ${ }^{8}$ The UNCTC covered a range of

6 Christian Aid, "Behind the mask: the real face of corporate social responsibility | Eldis," online: <https://www.eldis.org/document/A14595>.

7 United Nations Commission on Transnational Corporations, "United Nations Commission on Transnational Corporations: Report of the Secretariat on the Outstanding Issues in the Draft Code of Conduct on Transnational Corporations" (1984) 23:3 International Legal Materials 602-625. UN Commission on Transnational Corporations, Commission on Transnational Corporations: Report on the Special Session E/1983/17/Rev.1 (New York, 1983).

$8 \quad$ Christian Aid, supra note 6. 
MNC duties in the host state, such as respect for national sovereignty, adherence to economic and development goals, technology transfer, consumer protection, environmental protection, and disclosure of information. $^{9}$

The 1992 Earth Summit in Rio de Janeiro explicitly endorsed voluntary approaches and considered modern CSR's birth. ${ }^{10}$ CSR is now recognized as a universal principle since it is embedded in international declarations and agreements. The ILO's Tripartite Declaration of Principles Concerning Multinational Enterprises and Social Policy (ILO MNE Declaration) ${ }^{11}$ and the OECD's Guidelines for Multinational Enterprises (OECD Guidelines) ${ }^{12}$ are the two most prominent sources of CSR standards.

The ILO MNE Declaration is based on a tripartite consensus elaborated and adopted by governments, employers, and workers worldwide. The Declaration encourages multinational enterprises' positive contribution to economic and social progress, believing that MNEs can play an essential part by efficiently utilizing capital, technology, and labor. ${ }^{13}$ It includes parent companies and local entities. It sets out voluntary principles that all the parties should adhere to on general issues and specific issues related to

9 United Nations Commission on Transnational Corporations, supra note 6.

10 Christian Aid, supra note 6. Christian Aid, Bebind The Mask The Real Face of Corporate Social Responsibility (Christian Aid, 2004); Judith Richter, Codes in Context: TNC Regulation in an Era of Dialogues and Partnership (2002).

11 International Labor Organization (ILO), Tripartite Declaration of Principles Concerning Multinational Enterprises and Social Policy (Geneva: International Labor Organization, 2017). The ILO MNE Declaration was adopted by the governing body of the ILO at its 204th Session in 1977 and amended in 2000, 2006, and 2017.

12 OECD, OECD Guidelines for Multinational Enterprises (Paris: OECD Publishing, 2008); International Organization for Standardization (ISO), Contributing to the UN Sustainable Development Goals with ISO Standards (Geneva: International Organization for Standardization, 2018); United Nations, GUIDE TO THE GLOBAL COMPACT: A Practical Understanding of the Vision and Nine Principles (United Nations, 2003).

13 The ILO MNE Declaration has its definition for MNEs besides the standard legal definition. Under the Declaration, MNEs include enterprises, whether wholly or partially state-owned or privately owned, that own or control production, distribution, service, or other facilities outside the country in which they are based (ILO MNE Declaration [1]-[3], [6]). 
employment, working conditions, and industrial relations. The Declaration also includes host state and home state responsibilities. However, the Declaration does not consider the broader aspects of sustainable development that MNEs can adhere or promote during their commercial presence in host countries.

Most of the CSR standards embodied in the ILO MNE Declaration relate to labor issues, while the OECD Guidelines regulate the overall behavior of MNEs operating abroad. Thus, the CSR presented in the OECD Guidelines seems to be a comprehensive version of voluntary standards. However, most investment treaties do not provide a detailed inclusion of such standards, limiting workers' rights. This is because investors selectively adhere to voluntary standards that suit their business interests. Therefore, to give legal validity to this expanded version of CSR, it should be referred to in domestic investment law, investment treaties, and contracts.

The OECD Guidelines assert that MNEs play a vital role in the world economy and contribute to economic, social, and environmental progress through foreign investment initiatives. ${ }^{14}$ The Guidelines also suggest that MNEs can minimize and resolve difficulties arising in the course of business operations. The Guidelines avoid setting a precise definition for MNEs and are addressed to all entities within the structure of MNEs. ${ }^{15}$ They set out voluntary principles, as do the ILO MNE Declaration, OECD Declaration on International Investment, Multinational Enterprises, and other instruments. Accordingly, the OECD Guidelines cover a wide range of corporate behavior such as employment and industrial relations, the environment, combating bribery, consumer interests, science and technology, competition, and taxation. ${ }^{16}$ The CSR standards addressed in the General Policies section of the OECD Guidelines comprise special

14 OECD, supra note 12.

15 (ILO), supra note 11.

16 OECD, supra note 12. As of May 2010, the governments of 42 OECD and nonOECD countries adhere to the OECD Declaration on International Investment and Multinational Enterprises and related decisions. In addition, the OECD Guidelines were revised in 2011 to provide recommendations for the promotion of responsible global business conduct and are considered a leading international instrument on CSR. 
recommendations on $\mathrm{MNE}$ behavior, ensuring that MNEs' activities comply with the SDGs. ${ }^{17}$ This is the best model to ensure the responsive behavior of MNEs to relevant investment treaties.

Significantly, the OECD Guidelines provide an implementing mechanism that encourages MNEs to adopt voluntary standards meaningfully. Accordingly, National Contact Points are to be set up by the government of each OECD member or non-member state to promote responsible business conduct. Further, National Contact Points provide a mediation and conciliation platform for resolving practical issues of implementing the Guidelines and any allegations of non-compliance by companies. ${ }^{18}$

A growing number of firms have implemented voluntary codes of corporate conduct, market initiatives, or self-regulation that include commitments to observe ethical values in environmental, consumer protection, social, and labor standards. Except in rare situations, voluntary CSR statements or market forces alone are insufficient to provide accountability, and binding regulations increase to ensure MNEs' seriously involved in promoting meaningful development. ${ }^{19}$ This requires acknowledging CSR through an appropriate legal framework like BITs rather than limiting CSR to a selfregulating mechanism.

\section{THE MNC AS A PROMINENT ACTOR: AN ASSESSMENT}

It is widely accepted that MNCs are engines of economic growth that can enhance human rights values and environmental protection in capital receiving developing countries. ${ }^{20} \mathrm{MNCs}$ are among the world's largest firms, and their industrial operations differ according to their specialization

7 Ibid.

18 OECD, Annual Report on the OECD Guidelines for Multinational Enterprises 2017 (2018). In 2017, National Contact Points closed 34 specific instances and received 28 new specific instances. In some cases, agreements reached among parties included direct remedy to the submitters or changes to a company's operations and policies to mitigate impacts.

19 ICHRP, Beyond Voluntarism: Human Rights and the Developing International Legal Obligations of Companies (Versoix, 2002).

20 William H Meyer, "Human Rights and MNCs: Theory versus Quantitative Analysis" (1996) 18:2 Human Rights Quarterly 368-397. 
and own and control activities in several countries. ${ }^{21} \mathrm{MNCs}$, also referred to as MNEs and TNCs, are assessed based on the multi-nationality of their foreign affiliates and subsidiaries; the number of countries in which they operate; total assets, revenues or profits; international nature of their employees, stockholders, owners, and managers; and the oversees nature of their operations. ${ }^{22}$ They have the most direct influence on the structure and effects of FDI. ${ }^{23}$

The diffusion of technology through FDI is one of the factors supporting the classical theory of investment, which holds that foreign investment is wholly beneficial to develop economies. This theory focuses on the liberalization of the economy in developing countries. The theory behind the neo-liberal policies of powerful international organizations like the World Bank and the International Monetary Fund. ${ }^{24}$ Many have argued for a positive view of MNCs as assisting better environmental management in developing countries by exporting modern and less polluting technology. ${ }^{25}$ Governments and environmental groups have recognized the role of business in promoting environmental protection as primary partners for long-term environmental solutions, even though it is the primary polluter. ${ }^{26}$ In terms of foreign investment, large and powerful MNCs are more capable than some governments of developing countries in environmental management given their access to capital, research, and development capacity, market influence, ability to create and disseminate knowledge and products, and ability to engage in consensus-building dialogue at the domestic and international level. ${ }^{27}$ The Global Investment Competitiveness

${ }^{21}$ Jeffrey A Hart \& Joan Edelman Spero, The Politics of International Economic Relations, 5th edition ed (London: Routledge, 1997); John H Dunning \& Sarianna M Lundan, Multinational Enterprises, and the Global Economy (Cheltenham: Edward Elgar, 2008).

${ }^{22}$ Hart \& Spero, supra note 21.

23 United Nations Conference on Trade and Development (UNCTAD), Making FDI Work for Sustainable Development (Geneva: UNCTAD, 2004).

${ }^{24} \mathrm{M}$ Sornarajah, The International Law on Foreign Investment (Cambridge University Press, 2021).

25 David Hunter, James Salzman \& Durwood Zaelke, International Environmental Law and Policy (Thomson Reuters Foundation/ Foundation Press, 2011) at 1386.

${ }^{26}$ Ibid at 1386.

27 Ibid at 1386. 
Report 2017/2018 stressed the significance of MNCs in meeting the objectives of sustainable development. ${ }^{28}$ The report highlighted that "foreign investors are becoming increasingly prominent players in delivering global public goods, addressing climate change, improving labor conditions, setting global industry standards and delivering infrastructure to local communities." ${ }^{29}$

The environmental management strategies of MNCs may also influence the host government's and local businesses' environmental management. For instance, leading companies routinely publish environmental data in annual reports, conduct environmental audits of overseas facilities, seek third-party certification of their environmental management systems and go beyond mere compliance with regulations. ${ }^{30}$ The best practices of MNCs, such as management of skills, new ideas, and technological modernization, may guide local firms and personnel towards better environmental management and may influence the government to make environmental reforms. Shao identified such two possible aspects of MNCs in developing countries: MNCs tend to improve resource efficiency to abate environmental pollution problems of host states' domestic enterprises, and they support the development of host countries' environmental protection technology through knowledge diffusion, technology spillover, transfer of funds and other actions. ${ }^{31}$

There are criticisms of the negative behavior of MNCs in developing countries, particularly with environmental management and human rights abuses. Nevertheless, MNCs are the most prominent actors in foreign investment and are described as engines of development in developing countries. However, it is also generally accepted that these corporations can

28 Global Investment Competitiveness Report 2017/2018: Foreign Investor Perspectives and Policy Implications (World Bank Group, 2018).

29 Ibid at 1.

30 Ibid at 4-5.

31 Yanmin Shao, "Does FDI Affect Carbon Intensity? New Evidence From Dynamic Panel Analysis" (2018) 10:1 International Journal of Climate Change Strategies and Management 27-42 at 29. 
also harm the host states they operate. ${ }^{32}$ Human rights abuses can be categorized as either soft or hard violations of human rights. Soft violations include poor employment conditions and environmental degradations, while complex violations include child labor, murder, torture, and conspiring with an oppressive regime. ${ }^{33}$ Rubin stated:

Even in the national arena, the corporation has sometimes exacerbated fears. The aggregation of economic power that the device permits has often been viewed as powerful and not always responsive to popular concepts of the 'best interest' of the general public. ${ }^{34}$

The report on 'Development for all, or a privileged few? Business E' Human Rights in Southeast Asia' indicates the alarming patterns of human rights violations in Southeast Asia by foreign companies, which states that there were 289 human rights violations over the past ten years. ${ }^{35}$ The report also indicates that this will weaken laws to reduce pollution, ensure safe workplaces, and protect indigenous rights. ${ }^{36} \mathrm{MNCs}$ ' profit-earning motives neglect the other aspects of development such as poverty, inequality, and unemployment alleviation - these were largely unnoticed by MNCs. ${ }^{37}$ Further to, in some cases, MNCs fail to take adequate measures to clean up environmental effects caused by their business even when the government requests they clean up. ${ }^{38}$ Stiglitz accused MNCs of lousy behavior and stated:

32 M Sornarajah, The Settlement of Foreign Investment Disputes (Kluwer Law International, 2000) at 361.

33 J M Chanin, "The Regulatory Grass is Greener: A Comparative Analysis of the Alien Tort Claims Act and European Union's Green Paper on Corporate Social Responsibility" (2005) 12:2 Indiana Journal of Global Legal Studies at 747.

34 Seymour J Rubin, "Transnational Corporations and International Codes of Conduct: A Study of the Relationship Between International Legal Cooperation and Economic Development" (1995) 10:4 American University International Law Review. at 1278.

35 Irene Pietropaoli \& Bobbie Sta Maria, BRIEFING: Development for all, or a privileged few? Business and Human Rights in Southeast Asia (Business and Human Resource Centre, 2017) at 4.

36 Ibid.

37 K Aswathappa, International Business (McGraw Hill Education, 2015).

38 Joseph E Stiglitz, "Multinational Corporations: Balancing Rights and Responsibilities" (2017) 101 Proceedings of the ASIL Annual Meeting at 15. 
In some cases, when the adverse consequences of their actions are criticized, the MNCs plead that they are simply following the law: but such defenses are disingenuous, for they often work hard to make sure that the law is the law that suits them well and maximizes their profits. $^{39}$

Powerful MNCs also take advantage of limited liability to avoid excessive burdens. ${ }^{40}$ The characteristics and nature of MNCs and those of host states and home states make it very easy to achieve their objectives. For instance, the size and power of MNCs allow them to create a favorable environment in capital dependent developing countries; ${ }^{41}$ influence of their home government to get better terms in international treaties; ${ }^{42}$ lack of administrative capacities and technical experts in host states work in favor of $\mathrm{MNCs} ;{ }^{43}$ and sometimes MNCs, and the governments of the advanced industrial countries who represent their interests, take advantage of power and information asymmetries. ${ }^{44}$

For these reasons, capital receiving developing countries are usually unable to regulate or make demands of $\mathrm{MNCs}$, including that they observe development goals or comply with sustainable development norms. In most instances, developing countries agree to standard terms on investment protection in legally binding commitments and agreements. This influences

39 See further discussion on why foreign multinationals escape from environmental responsibility, Ibid at 16.

40 Ibid at 16.

41 As of December 2005, the retail giant Wal-Mart had 1.3 million employees and earned USD191.4 billion in revenue-more than the combined GDP of subSaharan Africa. PetroChina's market value is larger than the GDP of South Africa, a G-20 country. The profits of Russian oil company Gazprom equal the GDP of Jordan. These corporations are not only rich but politically powerful. If host governments decide to tax or regulate them in unfavorable ways, they can threaten to relocate-there is always another country that entices them with several incentives. See Aswathappa, supra note 37.

42 For example, see Stiglitz, supra note 38. at 16-8 cites a US drug company successfully pressuring the US Government to pressure a foreign country to issue a compulsory license, even when the issuance is within the framework of the WTO.

43 Ibid at $16-19$.

44 The US Government has bargained with dozens of countries on behalf of corporations. As a result, it knows likely and sensitive clauses or provisions that can significantly affect corporations, either benefits or costs. See Ibid. 
MNCs to choose developing countries for operations because their governments readily agree to such terms because of MNCs' enormous size and power. Thus, the behavior of MNCs is appreciated and criticized throughout the literature on environmental conservation and uphold human rights values. Nonetheless, the significance of MNCs for the promotion of sustainable development cannot be underestimated, as they are capable of upholding best practices and helping to implement laws in developing countries. Thus, they need to be regulated to derive the total benefit from foreign investment initiatives.

\section{A. Host State in Regulating MNC's Conduct}

As previously mentioned, most $\mathrm{MNCs}$ are powerful corporations that developing countries are unwilling or unable to regulate due to a lack of resources and other support. ${ }^{45}$ The domestic legal system may be weak and largely unregulated, influencing $\mathrm{MNC}$ s to choose that location. ${ }^{46}$ This minimizes the strict rules that MNCs are otherwise obliged to follow in their home territories. Conversely, the inefficiency of domestic laws and inadequate resources, expertise, and technology of developing countries may impose disadvantageous conditions for MNCs. ${ }^{47}$ This influences developing countries to create favorable and stable legal and environmental frameworks to attract FDI. ${ }^{48}$ Nevertheless, developing countries do not fail to recognize the negative impacts of MNCs and agree that their behavior should be internationally regulated to secure the interests of developing countries. For instance, some developing countries addressed the

45 See Murphy, supra note 2389.

46 Sarah Louise Joseph, "An Overview of the Human Rights Accountability of Multinational Enterprises" in Liability of Multinational Corporations Under International Law (Kluwer Law International, 2001) at 78.

47 Robert McCorquodale, "Waving Not Drowning: Kiobel Outside the United States" (2013) 107:4 The American Journal of International Law at 846.

48 S Bottomley \& D Kinley, "Corporations and Human Rights" in Commercial Law and Human Rights (Ashgate, 2002) at 60. 
limitations of host governments in regulating MNCs' conduct because of their enormous power and worldwide operations. ${ }^{49}$

To a certain extent, a few host governments have imposed measures to control unfriendly investment projects through their local laws and by including provisions related to non-economic objectives in their respective BITs. ${ }^{50}$ However, these mainly cover entry-level regulation of foreign investment. Regulating the behavior of MNCs primarily relates to the operational stage of investment projects, and their behaviors are monitored annually throughout an investment contract. Capital-dependent developing countries may not be able to monitor or follow up MNCs due to a lack of courage, resources, and experts and the power and size of MNCs. Regarding the inability to control $\mathrm{MNCs}$, every country regulates people and property within its territory-the 'territorial principle.' Additionally, the host government has an essential role in creating a 'level playing field' to regulate $\mathrm{MNC}$ behavior. It should ensure provisions regulating MNCs are included in its laws, treaties, and binding contracts. ${ }^{51}$ Host governments must be able to adopt mechanisms to monitor and enforce social and environmental compliance.

Generally, it would only be possible to regulate MNCs' behavior through legally binding instruments in developing countries. This is because most

49 Communication From China, Cuba, India, Kenya, Pakistan, and Zimbabwe (WTO Doc No WT/WGTI/W/152, Working Group on the Relationship Between Trade and Investment, WTO, 19 November 2002).

50 See the Preamble to the Protection of Investment Act, Act No 22 of 2015 (South Africa); Preamble to the Investment Promotion Act (2016) (Namibia); Foreign Investment Act (2014) (Cuba) Article 20; The Pyidaungsu Hluttaw Law No 40/2016 (Myanmar) Article 41.

51 See Norms on the Responsibilities of Transnational Corporations and Other Business Enterprises with Regard to Human Rights, UN Doc E/CN.4/Sub.2/2003/12/Rev.2 (2003) Article 1. The general obligation provides that states have the primary responsibility to promote, secure the fulfillment of, respect, ensure respect of and protect human rights recognized in international and national law, including ensuring that transnational corporations and other business enterprises respect human rights. Likewise, within their respective spheres of activity and influence, transnational corporations and other business enterprises must promote, secure the fulfillment of, respect, ensure respect of and protect human rights recognized in international as well as national law, including the rights and interests of indigenous peoples and other vulnerable groups. 
codes of conduct, market behavior, or ethics are voluntary mechanisms. The voluntary standard becomes effective when the international community adopts a multilateral treaty on the conduct of MNCs in developing countries that acknowledges the responsibilities and obligations of the home state, host state, and MNCs. Otherwise, governments should adopt binding regulations on MNC conduct at a territorial level to ensure MNC compliance with domestic laws and policies. However, the imposition of ambitious standards on MNCs is problematic. Firstly, it can be very costly. Secondly, effective laws are essential to define the roles and responsibilities of $\mathrm{MNCs}$ in upholding best practices to promote sustainable development in the capital receiving state. Moreover, foreign investors may be reluctant to agree to social, human rights, and environmental commitments where laws are ambiguous, uncertain, or ineffective. Thirdly, foreign-owned-corporations have already contributed to wealth creation in developing countries, so the fear exists that material changes to the operations of such corporations may affect the level of income, employment, and general standard of living in the entire country either positively or negatively. ${ }^{52}$ Most developing countries are reluctant to set laws governing MNCs, as they need this foreign investment for their economic growth. Consequently, capital-dependent developing countries show a constant willingness to attract more FDI through adopting more liberal approaches than competing similar countries.

In this climate, bringing in binding regulations on $\mathrm{MNCs}$ is a pipedream for a single developing country. Thus, the binding universal standard must be set internationally or regionally. Murphy observed that due to a vacuum of government regulation of MNCs in the developing world, these nonstate actors-a form of private regulation-have emerged to deal with the adverse social effects of MNC activity. ${ }^{53}$ The failure of such attempts by the international and regional community and the individual governments of developing countries demonstrates the need to adopt a universally recognized voluntary code of conduct in binding treaties or agreements,

52 H Jaffrey Leonard, "Multinational Corporations and Politics in Developing Countries" (1980) 32:3 World Policy at 456.

53 Murphy, supra note 2. 
such as BITs and investment contracts. This would recognize the accountability of contracting parties to uphold social, human rights, and environmental protections, provide better voluntary codes than MNCs' internal policies and produce a more balanced treaty. In addition, this would make MNCs accountable for violating voluntary principles, give them responsibilities, and most notably, influence arbitrators' decisions in dispute settlement processes, particularly when deciding the legality of expropriation and associated compensation.

\section{B. Due Diligence Test}

As previously discussed, including comprehensive CSR standards in investment treaties is essential to promote foreign investment for sustainable development. CSR standards demarcate the responsibilities of all actors in promoting responsible investment in the host country. The implementation of CSR standards depends on the due diligence test from a corporate, home, and host government perspective. From the corporate perspective, due diligence is generally understood as investigating the conduct of business to identify and manage commercial risks. ${ }^{54}$ Accordingly, the corporate perspective on due diligence is generally understood as confirming facts, data, and representations involved in a commercial transaction to determine the value, price, and risk of such transactions, including the risk of future litigation. ${ }^{55}$ According to Ruggie, due diligence is a process whereby companies ensure compliance with national laws and manage the risk of human rights harm to avoid it. ${ }^{56}$ The due diligence test clarifies MNCs' duty to 'not harm' while conducting

54 Jonathan Bonnitcha \& Robert McCorquodale, "The Concept of 'Due Diligence' in the UN Guiding Principles on Business and Human Rights" (2017) 28:3 European Journal of International Law at 899.

55 Olga Matin-Ortega, "Human Rights Due Diligence for Corporations: From Voluntary Standards to Hard Law at Last" (2013) 32:1 Netherlands Quarterly of Human Rights at 44, 51; Bonnitcha \& McCorquodale, supra note 53 at 901.

56 John Ruggie, Protect, Respect and Remedy: A Framework for Business and Human Rights. Report of the Special Representative of the Secretary-General on the Issue of Human Rights and Transnational Corporations and Other Business Enterprises, Human Rights Council, $8^{\text {th }}$ sess, Agenda Item 3, UN Doc A/HRC/8/5 (April 2008). 
business in the host state. ${ }^{57}$ It is bolstered by companies adopting comprehensive voluntary CSR standards. However, these voluntary standards sometimes impose liability when MNCs fail to adhere to social, human rights, or environmental commitments.

Adhering to the due diligence process is increasingly important to implement the OECD Guidelines. The OECD's 2017 Annual Report stated that governments' regulatory directives could present a strong incentive for companies to carry out due diligence. At the same time, domestic level expectations can create challenges for globally operating businesses to meet various international expectations. ${ }^{58}$ The OECD recently published its Due Diligence Guidance for Responsible Business Conduct, which is relevant to all sectors of the economy. ${ }^{59}$

From a host state perspective, a due diligence test is a crucial tool for measuring state responsibility for preventing or responding to abuses committed by businesses. ${ }^{60}$ The test highlights the duties of capitalreceiving states. Accordingly, a State must have taken severe or reasonable steps to prevent or respond to abuse by a private actor, including investigating and providing a remedy such as compensation. ${ }^{61}$ The most significant aspect of due diligence in developing standards is acknowledging how international and state practices can move from voluntary to normative standards. ${ }^{62}$ For instance, the OECD's work has focused on promoting policy coherence to responsible business conduct in the economic, environmental, and social spheres. ${ }^{63}$ Further, the OECD

57 '... the corporate responsibility to respect human rights [means], in essence, to do no harm' (John Ruggie, Presentation of Report to United Nations Human Rights Council, Special Representative of the Secretary-General, Geneva, 3 June 2008.

58 OECD, supra note 17 at 10.

59 Ibid.

60 OECD, OECD Due Diligence Guidance for Responsible Business Conduct (OECD, 2018). See also Matin-Ortega, supra note 55.; Madeleine Conway, "A New Duty of Care? Tort Liability from Voluntary Human Rights Due Diligence in Global Supply Chains" (2015) 40:2 Queen's Law Journal. at 741-5.

${ }^{61}$ (ICHRP), supra note 18 at 59.

62 See Matin-Ortega, supra note 54 at 61 . Bonnitcha \& McCorquodale, supra note 53 at 901 . Conway, supra note 60.

63 OECD, supra note 17 at 8-9. 
observes that in the context of global challenges concerning climate, poverty, and sustainable development, governments are increasingly committed to designing and implementing a robust policy framework that supports and promotes responsible business conduct. ${ }^{64}$ Without having such mechanisms at the domestic level, it is challenging to ensure MNC behavior that supports responsible business practices. However, the vulnerability of developing countries creates uncertainty that such regulatory directives will be observed by MNCs unless adopted universally or regionally.

The due diligence test may be extended to the responsibilities of states to third-party conduct. ${ }^{65}$ This was well explained in AAPL $v$ Sri Lanka, where the Tribunal aligned the due diligence test with the Roman law concept of taking reasonable steps to avoid harm. ${ }^{66}$ The Tribunal quoted Freeman: "Due diligence is nothing more nor less than the reasonable measures of prevention which a well-administered government could be expected to exercise under similar circumstances." ${ }^{67}$

Bonnitcha and McCorquodale started the contrasting view of the Tribunal on the due diligence standard, "absolute obligation which guarantees that no damages will be suffered, in the sense that any violation thereof creates a 'strict liability' automatically on behalf of the host state. ${ }^{68}$ They further argue that states are not strictly liable for transboundary environmental harm under international environmental law but must act diligently. ${ }^{69}$ This was stated in the Draft Articles on Prevention of Transboundary Harm From Hazardous Activities. For example, Article 3 states that the state of origin shall take all appropriate measures to prevent significant

64 Ibid.

${ }_{65}$ Bonnitcha \& McCorquodale, supra note 53 at 903.

${ }^{66}$ Asian Agricultural Products Ltd v. Republic of Sri Lanka (ICSID Case No ARB/87/3) Final Award, 27 June 1990 [75]-[77]. See also Ibid.

${ }^{67}$ Asian Agricultural Products Ltd v. Republic of Sri Lanka (ICSID Case No ARB/87/3) [77].

68 Ibid at 86. Bonnitcha \& McCorquodale, supra note 54.

${ }^{69}$ Ibid at 904. See Patricia W Birnie, Alan E Boyle' \& Catherine Redgwell, International Law and the Environment (Oxford University Press, 2009) at 217-18; International Law Commission, Draft Articles on Prevention of Transboundary Harm From Hazardous Activities, with Commentaries, UN Doc A/56/10 (2001) Article 3. 
transboundary harm or, at any event, minimize the risk thereof. However, to prevent environmental harm from foreign investment, every state has to act on its duty of care by observing the due diligence test to test whether foreign investment is beneficial to the host state's sustainable economic development. Moreover, the ICJ held in Pulp Mills on the River Uruguay that a state's duty to prevent harm is a customary rule with its origin in due diligence. ${ }^{70}$ The court referred to the Corfu Channel Case ${ }^{71}$ and cited every state's obligation not to allow its territory knowingly to be used for acts contrary to the rights of other states. Further, the court held that:

A state is thus obliged to use all the means at its disposal to avoid activities in its territory or any area under its jurisdiction, causing significant damage to the environment of another State. This court has established that this obligation 'is now part of the corpus of international law relating to the environment. ${ }^{72}$

Thus, home states have a responsibility to abide by the international law relating to the environment and a duty to prevent MNC activities that harm the environment or cause human rights violations in host states. States should adopt the necessary measures to protect the environment, and failure to act may make a state liable based on the due diligence test. It ensures the MNCs, host states, and home states adopt and implement the necessary measures to protect society, the environment, and human rights, supporting sustainable development. ${ }^{73}$

70 Pulp Mills on the River Uruguay (Argentina v Uruguay) (Judgment) (ICJ, General List No 135, 20 April 2010) [101] <http://www.worldcourts.com/icj/eng/decisions/ 2010.04.20_pulp_mills.htm> ('Pulp Mills case').

71 Corfu Channel Case (UKv Albania) (Merits) [1949] ICJ Rep 4, 22.

72 Pulp Mills case [101].

73 For instance, John Ruggie used due diligence in its broader sense about respect for human rights: 'a comprehensive, proactive attempt to uncover human rights risks, actual and potential, over the entire life cycle of a project or business activity, to avoid and mitigate those risks' (Report of the Special Representative of the Secretary-General on the Issue of Human Rights and Transnational Corporations and Other Business Enterprises, UN Doc A/HRC/11/13 (22 April 2009) at 71. See Radu Mares, "A Gap in the Corporate Responsibility to Respect Human Rights" (2010) 36:3 Monash University Law Review at 33. 


\section{Legalization of CSR Standards}

In most cases, voluntarism is not working for developing countries, as their laws are too fragile to monitor the behavior of powerful MNCs, and, often, powerful commercial interests clash with CSR standards. ${ }^{74}$ Pendleton described global corporate behavior and stated that resistance to regulation by the corporate world as a whole had left the worst corporate abusers effectively unrestrained and the victims of their actions without adequate means of redress. ${ }^{75}$

Christian Aid investigated several voluntary CSR standards, particularly in developing countries, and suggested that $\mathrm{MNCs}$ will not commit to upholding high standards and sustainable development norms, except through legally binding commitments to corporate social accountability. However, it demonstrated that human rights and conservation of the environment could not be a purely voluntary exercise. Therefore, it is time to shift from voluntary CSR to corporate social accountability with legally binding commitments. ${ }^{76}$ Binding regulations on CSR are necessary to curb the negative impacts of MNCs' conduct in developing countries, as their laws are weak and poorly enforced. As a result, many institutions and individuals have argued for binding regulations on CSR, either through government regulation or by adopting international regulations. ${ }^{77}$ Pendleton quoted Beyond Voluntarism, which persuades to adopt legally binding international human rights standards for MNCs. Further it argues that international human rights law must apply to corporations to constrain their power. There needs to be a deterrence principle governing their behavior, and victims need redress. ${ }^{78}$ Voluntary standards are inadequate to accountable MNCs for their environmental and human rights violations, particularly in developing countries. For instance, Christian Aid assessed three powerful companies-Shell in Nigeria, British American Tobacco and Coca-Cola-generally considered champions of CSR and proved that

${ }^{74}$ (ICHRP), supra note 19.

75 Andrew Pendleton, “The Real Face of Corporate Social Responsibility” (2004) 14:3

Consumer Policy Review at 81.

76 Christian Aid, supra note 6.

77 Pendleton, supra note 75. (ICHRP), supra note 19.

78 Ibid. 
their voluntary commitments are inadequate to ensure good practice or curb extreme corporate transgression. ${ }^{79}$

The misconduct of MNCs in developing countries reaffirms the urgent need for legally enforceable mechanisms and norms to prevent recurrences. ${ }^{80}$ In these cases, one can argue that $\mathrm{MNCs}$ have not only breached their voluntary commitments in favor of their commercial interest but have also breached their professional standards. Pendleton observed that in these cases, each company was not accused of contravening domestic laws but of failing to meet its own ethical, voluntary professional standards. Therefore, voluntarism can hold them accountable. ${ }^{81}$ However, the power of MNCs needs to be constrained by laws and regulations at the domestic and international levels to curb irreparable damage to the environment and social wellbeing.

The international community has attempted to bring in a non-voluntary code to make companies directly liable for their harmful conduct, but this was unsuccessful. On 13 August 2003, the UN Sub-Commission on the Promotion and Protection of Human Rights imposed human rights obligations on TNCs for their harmful business conduct by approving a draft instrument, the Norms on the Responsibilities of Transnational Corporations and Other Business Enterprises with Regard to Human Rights. ${ }^{82}$ This instrument was a landmark step towards organizing TNCs and other business enterprises to uphold human rights values and make them responsible for violating such values during business conduct by adopting non-voluntary standards. The instrument would have made TNCs directly responsible for their human rights violations in capitalreceiving states. The instrument encompassed many human rights issues

79 Christian Aid, supra note 6.

80 Communication From China, Cuba, India, Kenya, Pakistan, and Zimbabwe (WTO Doc No WT/WGTI/W/152, Working Group on the Relationship Between Trade and Investment, WTO, 19 November 2002) at 3.

81 Pendleton, supra note 75 at 77.

82 Norms on the Responsibilities of Transnational Corporations and Other Business Enterprises with Regard to Human Rights, UN Doc E/CN.4/Sub.2/2003/12/Rev.2 (2003). 
linked to business practices, such as environmental law, human rights law, humanitarian law and consumer protection. ${ }^{83}$ Its Preamble acknowledged:

Universality, indivisibility, interdependence, and interrelatedness of human rights, including the right to development, entitles every human and all peoples to participate in, contribute to, and enjoy economic, social, cultural, and political development. Thus, all human rights and fundamental freedoms can be fully realized. ${ }^{84}$

The instrument laid down several responsibilities of TNCs and other business enterprises, including environmental protection norms. Article 14 emphasized that TNCs should carry out their business activities under national and international environmental regulations to promote sustainable development. ${ }^{85}$

Initially, the instrument was designed for a non-voluntary framework to create direct obligations for TNCs with an enforcement mechanism. However, the UN Commission on Human Rights abandoned the instrument due to fierce opposition from various states and the business community, including the International Chamber of Commerce and the International Organization of Employers. ${ }^{86}$ In 2005, this Commission gave a mandate for a Special Representative of the UN Secretary-General to address business and human rights. The Special Representative's final report, released in 2011, reasserted the state's duty to protect human rights from abusive business practices while also imposing responsibilities on businesses to respect human rights. ${ }^{87}$

83 See David Weissbrodt \& Muria Kruger, "Norms on the Responsibilities of Transnational Corporations and Other Business Enterprises with Regard to Human Rights" (2003) 97:4 American Journal of International Law at 901.

${ }^{84}$ Norms on the Responsibilities of Transnational Corporations and Other Business Enterprises with Regard to Human Rights, UN Doc E/CN.4/Sub.2/2003/12/Rev.2 (2003) preamble.

85 Ibid Article 14.

86 See Weissbrodt \& Kruger, supra note 82 at 138 . On the reasons for the abandonment of the draft norms, see Pini P Miretski \& Sascha-Dominik Bachmann, "The UN 'Norms on the Responsibility of Transnational Corporations and Other Business Enterprises with Regard to Human Rights': A Requiem” (2012) 17:1 Deakin Law Review at 8.

87 Weissbrodt \& Kruger, supra note 83 at $138-139$. 


\section{LEGAL COHERENCE AND COORDINATION}

\section{A. National Laws of Foreign Investment: A Way Forward}

The inclusion of sustainable development norms in domestic foreign investment laws has been gaining considerable attention to ensure policy coherence and space for the right to regulate. Accordingly, some countries leveraged their own comprehensive domestic foreign investment laws to avoid vagueness and provide legal certainty, thereby meeting sustainable development norms encompassing sustainable development language similar to modern/third-generation BITs. ${ }^{88}$ Domestic foreign investment laws are evolving to achieve the current needs of development. They coexist with national policies and international standards on sustainable development norms, intuit MNCs to uphold voluntary standards seriously. ${ }^{89}$ For instance, Investment Law No 72 of 2017 (Egypt) Article 15 explicitly refers to CSR standards, ${ }^{90}$ and ensures foreign investors comply with domestic legislation. ${ }^{91}$ National foreign investment laws further also pledge to refuse investments that lead to environmental degradation. The Namibia Investment Promotion Act (2016) details criteria for investment approvals. Approval mainly considers contributions to redressing social and economic imbalances, ${ }^{92}$ contribution to minimizing negative impacts and enhancing environmental benefits. ${ }^{93}$ Domestic foreign investment laws of some developing countries have understood that the significance of encompassing responsible behavior is somewhat impressive.

88 See generally, S. Dawood, "Regulating Responsible Business Practices for HumanCentered SDS: An Analysis of Recent Developments of International Investment Legal Framework of Developing Countries", Proceedings of SLIIT International Conference on Advancements in Sciences \& Humanities, 2020.

89 See Investment Law No 72 of 2017 (Egypt); Law on Investment (2014), Law No 67/2014/QH13 (Vietnam); Law on Investment Promotion (2016) (Laos); The Pyidaungsu Hluttaw Law No 40/2016 (Myanmar).

90 Investment Law No 72 of 2017 (Egypt) Article 15.

91 Law No 5 of 2007 on Capital Investment (Indonesia) arts 15, 16; Law on Investment Promotion (2016) (Laos) rt 72; The Pyidaungsu Hluttaw Law No 40/2016 (Myanmar) Article 65; Investment Act (2016); Investment Promotion Act, Law No 199 of 2016 (Namibia) s 18; Protection of Investment Act, Act No 22 of 2015 (South Africa) s 4.

92 Investment Promotion Act (2016) (Namibia) ss 14(b)-(e).

93 Ibid at 14(i). 


\section{B. Contextualizing CSR Standards in the BITs: A New Approach}

Since the failure of attempts to bring internally binding instruments on the conduct of MNCs, the recent BITs and Model BITs contain clauses outlining the responsibilities and duties of contracting parties. For instance, agreeing not to lower environmental standards, uphold human rights and workers' rights, and comply with the domestic law are a few significant features of recently concluded BITs ${ }^{94}$ and Model BITs. ${ }^{95}$ A considerable number of recent BITs include such clauses to ensure environmental commitments made during the entry-level and operational stage of foreign investment are upheld. It generates environmentally better projects aligned with sustainable development norms. Besides, a few recent BITs include an expanded version of the CSR voluntary standard, so it seems actors are gradually recognizing corporate social accountability and imposing specific obligations on foreign investors. However, this is possible only through BITs, as attempts to impose standards of good behavior through multilateralism have generally failed to garner political support (the UNCTC and Norms on the Responsibilities of Transnational Corporations and Other Business Enterprises concerning Human Rights). ${ }^{96}$ Few recent BITs recognize the importance of contextualizing CSR standards beyond voluntary standards. Thus, for example, the recent Argentine BITs contain a provision with CSR, which reaffirms the

94 Investment Promotion and Protection Agreement between the Government of Federal Republic of Nigeria and the Government of Republic of Singapore (date of signature 4/11/2016) Nigeria-Singapore BIT; Agreement between the Government of Japan and the Government of Republic of Kenya for the Promotion and Protection of Investment (entered into force 24/02/2017) (Japan- Kenya BIT); Agreement Between Canada and Mongolia for the Promotion and Protection of Investments (date of entry into force 24/02/2017) (Canada-Mongolia BIT).

95 Czech Republic Model BIT 2016 (date of adoption 28/12/2016); Azerbaijan Model BIT 2016; India Model BIT 2015 (date of adoption 28/12/2015); Serbia Model BIT 2014; The Netherlands Model BIT 2019 (date of adoption 22/03/2019); Norway Model BIT (draft) 2015.

96 Vid Prislan \& Ruben Zandvliet, "Mainstreaming Sustainable Development into International Investment Agreements: What Role for Labour Provisions?" in International Investment Law and Development: Bridging the Gap (Edward Elgar Publishing, 2015) at 417; Norms on the Responsibilities of Transnational Corporations and Other Business Enterprises with Regard to Human Rights, UN Doc E/CN.4/Sub.2/2003/12/Rev.2 (2003). 
voluntary standards developed by intentional organizations. ${ }^{97}$ For instance, Argentine-Qatar BIT includes that "investors operating in the territory of the host Contracting Party should make efforts to voluntarily incorporate internationally recognized standards of CSR into their business policies and practices." ${ }^{98}$ However, some recent BITs have expanded coverage of CSR standards. For example, the Canada-Mongolia BIT ${ }^{99}$ and Canada-Guinea $\mathrm{BIT}^{100}$ recognized expanded voluntary standards of CSR covering issues such as labor, the environment, human rights, community relations, and anti-corruption measures. ${ }^{101}$ The Brazil-Malawi BIT ${ }^{102}$ includes a more comprehensive CSR standard, with Article 9(1) stating:

Investors and their investment shall strive to achieve the highest possible level of contribution to the sustainable development of the Host Party and the local community through the adoption of a high degree of socially responsible practices, based on the voluntary principles and standards set out in this Article. ${ }^{103}$

Further, the Brazil-Malawi BIT ensures that investors and their investment shall develop their best efforts to comply with the voluntary principles listed in the Article for responsible business conduct and

97 The Reciprocal Promotion and Protection of Investments between the Argentine Republic and the State of Qatar (date of signature 06/11/2016) Article 12. (Argentina-Qatar BIT); Agreement Between the Argentine Republic and Japan (date of signature 01/12/2018) Article 17 (Argentine-Japan BIT); Reciprocal Promotion and Protection of Investments between the Argentine Republic and the United Arab States (date of signature 16/04/2018) Article 17 (Argentina-UEA).

98 (Argentina-Qatar BIT) Article 12.

99 (Canada-Mongolia BIT) Article 14.

${ }^{100}$ Agreement for the Promotion and Reciprocal Protection of Investments between Canada and the Republic of Guinea (date of entry into force 27/03/2017) art. 16. (Canada-Guinea BIT).

${ }^{101}$ Reciprocal Promotion and Protection of Investments between the Government of Kingdom of Morocco and the Government of the Federal Republic of Nigeria (date of signature 03/12/2016) Article 15 (Morocco -Nigeria BIT); Investment Promotion and Protection Agreement between the Government of the Federal Republic of Nigeria and the Government of the Republic of Singapore (date of signature 04/11/2016) Article 11 (Nigeria-Singapore BIT).

${ }^{102}$ Investment Cooperation and Facilitation Treaty between the Republic of Brazil and Republic of Malawi (date of signature 25/06/2015) (Brazil-Malawi BIT).

${ }^{103}$ Ibid Article 9(1). 
consistent with the laws adopted by the Host Party receiving the investment. ${ }^{104}$ The Brazil-Malawi BIT lists several voluntary CSR standards to be upheld by the investment-receiving states. These CSR standards are primarily (a) ensuring sustainable development, (b) stimulating economic, social, and environmental development, (c) ensuring the human rights of those involved in the companies' activities, (d) encouraging local capacity building, (e) refraining from seeking exemptions relating to the environment, health, security, work, or financial incentives, or other issues, and (f) supporting and maintain sound corporate governance principles and good practices, and develop and apply selfregulatory practices. ${ }^{105}$ The most recent BIT concluded between BrazilIndia ${ }^{106}$ emphasizes the adaptation of a high degree of socially responsible practices to achieve the highest possible contribution to the sustainable development of the host state. Further emphasizes, among others, compliance to voluntary principles and standards for responsible business conduct and consistent with the laws adopted by the host state. ${ }^{107}$

CSR accountability needs to be ensured within the relevant local legal framework. As previously discussed, developing countries' lack of resources and technical expertise poses difficulties in regulating MNCs in sustainable development and internationally adopted codes of conduct. Adherence to expanded CSR standards could promote socially responsible MNC behavior and prevent harm to the environment and social wellbeing of the developing world. However, individual companies and enterprises should also be encouraged to draft their investment strategies that comply with RBP and responsible investments. A few international organizations encourage MNCs to comply with social and environmental norms and ensure accountability and partnership. For example, the UN-supported

\footnotetext{
${ }^{104}$ Brazil-Malawi BIT Article 9(2).

${ }^{105}$ Brazil-Malawi BIT Article 9(2)(a)-(1).

${ }^{106}$ Investment Cooperation and Facilitation Treaty between the Republic of Brazil and the Republic of India (date of signature 25/01/2020) (Brazil-India BIT).

${ }^{107}$ Brazil-India BIT, Article 22.
} 
PRI provides steps for crafting investment strategies, particularly for asset owners (see below Figure 1). ${ }^{108}$

\begin{tabular}{|c|c|c|c|c|c|}
\hline (1) & Context & $\begin{array}{l}\text { (2) Vision \& } \\
\text { mission }\end{array}$ & $\begin{array}{l}\text { Investment } \\
\text { principles }\end{array}$ & $\begin{array}{l}\text { tion } \\
\text { citategy }\end{array}$ & \\
\hline - & $\begin{array}{l}\text { Gather fact base on } \\
\text { external trends (e.g. } \\
\text { social, technological, } \\
\text { economic, } \\
\text { environmental, } \\
\text { political/regulatory). } \\
\text { Assess your } \\
\text { organisation's } \\
\text { capabilities and } \\
\text { position in the } \\
\text { market. } \\
\text { Understand } \\
\text { the personal } \\
\text { investment } \\
\text { convictions of } \\
\text { key players in your } \\
\text { organisation (e.g. } \\
\text { regarding impact). }\end{array}$ & $\begin{array}{l}\text { Develop/realign } \\
\text { vision of how } \\
\text { society and } \\
\text { investment will } \\
\text { develop (e.g. } \\
\text { demographic } \\
\text { change, changing } \\
\text { beneficiary/ } \\
\text { customer needs/ } \\
\text { expectations, } \\
\text { regulatory change). } \\
\text { Clearly specify/ } \\
\text { reassert your } \\
\text { mission (e.g. } \\
\text { including the } \\
\text { breadth/extent of } \\
\text { your fiduciary duty). }\end{array}$ & $\begin{array}{l}\text { Develop specific } \\
\text { investment } \\
\text { principles/beliefs } \\
\text { (e.g. on market } \\
\text { efficiency, ESG } \\
\text { incorporation, active } \\
\text { ownership), for } \\
\text { use in: } \\
\text { " investment } \\
\quad \text { strategy } \\
\text { selection; } \\
\text { = investment } \\
\text { decision- } \\
\text { making }\end{array}$ & $\begin{array}{l}\text { Define medium- } \\
\text { and long-term } \\
\text { ambitions (e.g. on } \\
\text { financial return, } \\
\text { risk appetite, ESG } \\
\text { considerations), and } \\
\text { criteria to evaluate } \\
\text { them by. } \\
\text { Create strategy } \\
\text { scenarios, } \\
\text { combining options } \\
\text { of where to focus } \\
\text { (e.g. geographies, } \\
\text { asset classes) and } \\
\text { how to succeed (e.g. } \\
\text { sourcing). } \\
\text { Evaluate and select } \\
\text { an investment } \\
\text { strategy. }\end{array}$ & $\begin{array}{l}\text { - Plan and monitor: } \\
\text { - KPIs, } \\
\text { incentives and } \\
\text { organisation } \\
\text { structures; } \\
\text { - } \quad \begin{array}{l}\text { governance, } \\
\text { culture, } \\
\text { behavior and } \\
\text { responsibilities }\end{array} \\
\text { - Revise investment } \\
\text { policy, tactical/ } \\
\text { operational asset } \\
\text { allocation and } \\
\text { manager RfPs. } \\
\text { - Adjust strategy as } \\
\text { needed. }\end{array}$ \\
\hline
\end{tabular}

Figure 1: Crafting an Investment Strategy $y^{109}$

The implementation guidance strategies embodied in these five steps should be followed conscientiously by individual enterprises as a selfregulation mechanism in compliance with internationally recognized voluntary standards. ${ }^{110}$ The developing world agrees that MNCs and other business enterprises are responsible for respecting human rights, protecting the environment, and promoting sustainable development. ${ }^{111}$ The efficacy

${ }^{108}$ Mark Kolmar, Asset Owner Strategy Guide: How to Craft an Investment Strategy (PRI, 2018).

${ }^{109}$ Ibid at 7.

${ }^{110}$ Ibid.

${ }^{111}$ See generally on TNCs and human rights, Contribution of the United Nations System as a Whole to the Advancement of the Business and Human Rights Agenda and the Dissemination and Implementation of the Guiding Principles on Business and Human Rights, UN Doc A/HRC/RES/21/5 (16 October 2012) preamble [5]. Council of Europe, Committee of Ministers, Declaration of the Committee of Ministers on the UN Guiding Principles on Business and Human Rights (16 April 2014) [3]. Antal Berkes, 'Extraterritorial Responsibility of the Home States for MNCs Violations of Human Rights' in Y Radi (ed), Research Handbook on Human Rights and Investment (Edward Elgar Publishing, 2018) 304. Draft Plan of Implementation of the World Summit on Sustainable Development, UN Doc A/CONF.199/L.1 (26 June 2002) [18], [49]. 
of voluntary standards mainly depends on whether MNCs regard them as equally important as legally binding commitments.

Accordingly, MNCs' commitment to promoting sustainable development norms depends on adopting, acknowledging, and accepting CSR standards as strict internal policies and encouraging business partners, agencies, and supply chains to uphold best business practices in capital-receiving developing countries. Contracting parties adopting appropriate new clauses in BITs and investment agreements to outline the rights and obligations of MNCs for the promotion of sustainable development would be a considerable shift from voluntarism to mandatory standards. However, there is a general lack of acceptance of CSR in foreign investment laws of some developing countries because they are with first/second generation treaties, and often, CSR remains a voluntary standard in these countries.

\section{Non-Corporate Reporting: An Inevitable Commitment}

Non-corporate reporting systems aim to confirm the corporate social activities that enterprises have undertaken to establish good practices in promoting social and human rights and environmental protection. This reporting includes more than the financial aspects of an enterprise. For example, the Inter-Agency Working Group on the Private Investment and Job Creation Pillar of the G20 Multi-Year Action Plan on Development states that reporting has become a common expectation placed on companies that want to be viewed as socially responsible. ${ }^{112}$ They request that companies publish an annual report on corporate issues. In a few countries-Denmark, Sweden, the Netherlands, Norway, and France-the law mandates publishing an annual report, while in other countries, this remains voluntary. ${ }^{113}$

If countries have a tradition of acknowledging CSR as a voluntary standard, companies, and enterprises in those countries should communicate their CSR pledges through annual non-corporate reporting to relevant

112 (IAWG), supra note 4. United Nations, supra note 4.

113 A D Martin \& D J Hadley, "Corporate environmental non-reporting - a UK FTSE 350 perspective" (2008) 17:4 Business Strategy and Environment at 245-246. 
stakeholders. It is the only report that communicates companies' performance regarding CSR voluntary standards and is considered a powerful communication tool by legitimacy theory, decision usefulness theory, and communication theory. ${ }^{114}$ The basic idea of these theories is that companies should disclose all their information on social and environmental impact, so the public can be aware of this performance and observe whether companies have undertaken various socially desirable commitments in compliance with CSR standards. If a company has failed to meet agreed social and environmental norms, society can act against the company. Moreover, this ensures company survival, rewards environmental and social performance, and ensures transparency. ${ }^{115}$ Non-corporate reporting is also called sustainability reporting as defined in the Sustainability Reporting Guidelines. ${ }^{116}$

Voluntary standards on CSR, due diligence, and non-corporate reporting are primarily meant to ensure responsible business practices by all actors in foreign investment and are crucial to promoting responsible investment. In addition, they all help develop norms and standards on sustainable development, ensure good governance of natural resources, promote transparency and, thus, uphold the rule of law.

The OECD Guidelines encourage MNEs to provide information on a broader set of topics such as internal company performance measures, timely and accurate disclosure of all corporate information related to their

${ }^{114}$ P Rikhardsson, R J A Andersen \& H Bang, "Sustainability Reporting on the Internet: A Study of the Global Fortune 500" (2002) 40 Greener Management International 57-75. Martin \& Hadley, supra note 113.

${ }^{115}$ J Guthrie \& L D Parker, "Corporate Social Reporting: A Rebuttal of Legitimacy Theory" (1989) 19:76 Accounting and Business Research 345-352. See also A D Martin \& C Deegan, "The Legitimizing Effect of Social and Environmental Disclosures - A Theoretical Foundation" (2002) 15:3 Accounting, Auditing, and Accountability Journal at 282-311.

116 Sustainability reporting is a broad term synonymous with other terms used to describe economic, environmental, and social impacts (e.g., triple bottom line and corporate responsibility reporting). See Global Reporting Initiative, Sustainability Reporting Guidelines, 2000-2011, Global Reporting Initiatives, 3. Several initiatives promote a standardized CSR reporting framework (e.g., UNCTAD's ISAR Working Group, Global Reporting Initiative, Carbon Disclosure Standards Board, and International Integrated Reporting Committee). 
financial situation, performance, ownership, and governance, including remuneration plans and incentive schemes, and non-financial reporting. This ensures disclosure of social, environmental, and risk reporting related to greenhouse gas emissions and biodiversity ${ }^{117}$ and extends to subcontractors and suppliers of joint ventures to ensure all partners monitor environmentally harmful activities. ${ }^{118}$ By complying with the OECD Guidelines' requirements, companies demonstrate socially acceptable practices, which is crucial to promoting sustainable development. ${ }^{119}$ Domestic law should also impose legal requirements for non-corporate reporting or sustainability reporting to ensure that MNCs adhere to voluntary CSR standards on social and environmental protection. This requirement should be extended to private and public companies alike.

\section{Remedial Mechanism: Home State as A Competent Forum}

Besides extraterritorial home state statutes, plaintiffs can also use home state courts because of a lack of resources to sue the parent company domestically (in the host state). These are generally known as forum conveniens cases decided in the home state courts where the parent company is domiciled. Lubbe $v$ Cape plc ${ }^{120}$ and Chandler v. Cape plc $c^{121}$ are significant in this regard.

The Lubbe case succeeded with its plea of forum non-conveniens. Lubbe was an employee at the asbestos manufacturing, South African subsidiary company of UK parent company Cape plc. Cape plc was a public limited

117 OECD, supra note 18.

${ }^{118}$ Ibid.

${ }^{119}$ Non-OECD countries that adhere to the OECD Guidelines are Azerbaijan, Cameroon, Chinese Taipei, Colombia, Croatia, Egypt, Estonia, Haiti, Indonesia, Israel, Jamaica, Kazakhstan, Kenya, Latvia, Liberia, Lithuania, Malaysia, Mongolia, Peru, Russia, Singapore, South Africa, Tunisia, Ukraine, Uzbekistan, Venezuela, Vietnam, and Yugoslavia. See OECD, 'OECD Proceedings, Non-Member Economies and the OECD Guidelines for Multinational Enterprises, Paris 12 December 2000' (Report, OECD, 2001).

${ }^{120}$ Lubbe v Cape plc [2000] 4 All ER 268 (HL); Lubbe and Others v Cape plc [2000] 1 WLR 1545.

${ }^{121}$ Chandler v. Cape plc [2012] EWCA civ 525. 
company incorporated in England that owned several subsidiary companies in South Africa engaging in mining, processing, and selling asbestosrelated products. Lubbe was injured by exposure to asbestos and related products in South Africa. The plaintiff's central allegation against the parent company was a failure to adopt appropriate mechanisms to ensure the safety and health of employees of its subsidiaries and people living in the vicinity. The parent company breached a duty of care towards its subsidiary company employees in South Africa. ${ }^{122}$ The main plea of the defendants was forum non-conveniens. In the first instance, it was held that South Africa was the appropriate forum. ${ }^{123}$ However, on appeal, the Court of Appeal concluded that the defendant had not clearly and distinctly proved that South Africa was the most appropriate forum and, therefore, allowed the plaintiffs appeal. ${ }^{124}$ This was one of 3,000 similar claims against Cape plc, and all these cases proceeded as a group action. ${ }^{125}$ The defendant applied for a stay of all the proceedings against it. Buckley J decided that South Africa was clearly and distinctly the more appropriate forum for the trial of this group action. There were no sufficient reasons for nevertheless refusing a stay. ${ }^{126}$ The claimants then appealed to the House of Lords, which did not doubt at all that the defendants had discharged the burden of showing that South Africa was clearly and distinctly the more appropriate forum for the trial of these claims. ${ }^{127}$

The forum non-conveniens plea further can be scrutinized by analyzing Lord Kinnear's judgment in Sim $v$ Robinow, ${ }^{128}$ he stated that the plea could never be sustained unless the court is satisfied that another Tribunal has competent jurisdiction. The case may be tried more suitably for the interests of all the parties and the ends of justice. ${ }^{129}$ In this case, the court

\footnotetext{
${ }^{122}$ Lubbe and Others v Cape plc [2000] 1 WLR 1545.

${ }^{123}$ Ibid.

${ }^{124}$ Ibid.

${ }^{125}$ Ibid.

${ }^{126}$ Lubbe [2000] 1 Lloyd's Rep 151.

${ }^{127}$ Lubbe and Others v Cape plc [2000] 1 WLR 154, 1554; C G J Morse, 'Not in the Public Interest? Lubbe v. Cape PLC' (2002) 37 Texas International Law Journal 541.

${ }^{128}$ Sim v Robinow [1892] 19 R 665, 668.

${ }^{129}$ Lubbe and Others v Cape plc [2000] 1 WLR 1545, 1554.
} 
adopted the Spiliada test to ensure forum convenience. In the Spiliada case, ${ }^{130}$ it was stated:

The basic principle is that a stay will only be granted on the ground of forum non-conveniens where the court is satisfied that there is some other available forum, having competent jurisdiction, which is the appropriate forum for the trial of the action, i.e., in which the case may be tried more suitably for the interests of all the parties and the ends of justice. ${ }^{131}$

Chandler v. Cape plc was one of the first cases where the Court of Appeal imposed liability on a parent company for breach of its duty of care to an employee of its subsidiary. ${ }^{132}$ The Court of Appeal judgments address the possibilities of seeking damages in tort claims from a parent company. In this case, the claimant worked as a brick loader in the defendant company and suffered from asbestosis due to migrating dust from asbestos production. As a result, the claimant brought a claim against the parent company, alleging that it owed a direct duty of care to the employees of its subsidiary company to advise on or to ensure a safe system of work for them. ${ }^{133}$ The court examined the relationship between the parent and subsidiary company to see whether the parent company should be held responsible for the health and safety of its subsidiary company's employees. The court found no need for absolute control by a parent company of its subsidiary to find a duty of care. However, the law might impose such a duty on a parent company for the health and safety of employees of its subsidiary. ${ }^{134}$

The court found that the businesses of the two companies were in a relevant respect the same. The parent company had superior knowledge of a relevant aspect of its subsidiary's health and safety protocols. It knew

${ }^{130}$ Spiliada Maritime Corp v Cansulex Ltd [1987] AC 460, 476.

${ }^{131}$ Lubbe and Others v Cape plc [2000] 1 WLR 1545, 1554.

${ }^{132}$ Ibid at 1545; Martin Petrin, 'Assumption of Responsibility in Corporate Groups: Chandler v Cape plc' (2013) 76 Modern Law Review 603, 603.

${ }^{133}$ Chandler v. Cape plc [2012] EXCA civ 525, 3111.

${ }^{134}$ Ibid at 3111-3112. 
about the subsidiary's unsafe work system and should have ensured that its employees used that superior knowledge for their protection. ${ }^{135}$

The court held that it had assumed a duty of care either to advise the subsidiary on what steps it had to take to provide employees with a safe work system or to ensure that those steps were taken. In those circumstances, the defendant owed a direct duty of care to employees of the subsidiary company. There had been an omission to advise on precautionary measures that had resulted in injury to the claimant. ${ }^{136}$ The BHP lawsuit ${ }^{137}$ is another example of extraterritorial jurisdiction for tort claims on environmental degradation. The case was successfully lodged in the Victorian courts against Australian-based corporation BHP for environmental degradation committed in the territory of Papua New Guinea. In 1996, BHP and the plaintiffs agreed to a settlement for approximately $\mathrm{A} \$ 40$ million as compensation and dredging tailings from the river to limit further damage through an out-of-court settlement. ${ }^{138} \mathrm{In}$ 2001, BHP merged with Billiton, and in 2002, withdrew from its Ok Tedi mine and transferred its 52 percent equity to the Papua New Guinea Sustainable Development Programme Limited. ${ }^{139}$

The European civil law legal system allows civil claims attached to criminal proceedings (partie civile). ${ }^{140}$ However, McCorquodale observed the unwillingness of public prosecutors to bring civil tort claims. ${ }^{141}$ For instance,

135 Ibid.

${ }^{136}$ Ibid. Arden LJ held: In these circumstances, there was, in my judgment, a direct duty of care owed by Cape to the employees of Cape Products. In addition, there was an omission to advise on precautionary measures even though it was doing research. That research had not established (nor could it establish) that the asbestosis and related diseases were not caused by asbestos dust. Moreover, while I have reached my conclusion in my own words and following my route, it turns out that, in all essential respects, my reasoning follows the judge's analysis in paras 61 and 72-75 of his judgment. See Chandler V Cape plc, 3131.

${ }_{137}$ Dagi v Broken Hill Proprietary Co Ltd [1997] 1 VR 428.

${ }^{138}$ Business and Human Rights Resource Centre, BHP Lawsuit (re Papua New Guinea) <https://www.business-humanrights.org/en/bhp-lawsuit-re-papua-newguinea>; Dagi v Broken Hill Proprietary Co Ltd (No 2) [1997] 1 VR 428.

139 Ibid.

${ }^{140}$ McCorquodale, supra note 46 at 849.

${ }^{141}$ Ibid. 
the Akpan case ${ }^{142}$ involved a breach of the duty of care by the Shell parent company and its Nigerian subsidiary. The court concluded that the court held that in this instance, Nigerian law did not allow for the parent corporation to be liable. Nevertheless, the rulings indicate that such claims could be brought in civil law legal systems. ${ }^{143}$ The court observed a more limited approach than Chandler. ${ }^{144}$

\section{CONCLUSION}

Applying CSR standards in capital-dependent developing countries was only possible when corporate, home state, and the host government took appropriate actions at the policy level. Although internationally recognized voluntary standards for self-regulation should be incorporated into the internal policies of MNCs, the lack of legal commitment and the dubious implementation of such standards hinders this approach. It argued for a legally binding mechanism to improve CSR standards and suggested that incorporating an expanded form of CSR standards into an investment treaty and the domestic foreign investment laws of the host states would make it possible to provide accountability and move from voluntarism to mandatory standards. The domestic foreign investment laws of the host states would make it possible to provide accountability and move from voluntarism to mandatory standards. It highlighted the importance of the due diligence test that emphasizes the role of actors in implementing CSR standards to overcome practical difficulties. Additionally, applying extraterritorial jurisdiction by home state laws may enable recourse for damages or compensation from MNCs, primarily through tort claims, including convenient forum actions that prevail in US laws, UK common law, and European civil law. These will help reduce severe environmental and human rights violations by MNCs in capital-dependent host countries, but the future application of such laws remains uncertain.

\footnotetext{
${ }^{142}$ Akpan v Royal Dutch Shell PLC, Arrondissementsrechtbank Den Haag [District Court of the Hague], 30 January 2013, Case no C/09/337050/HA ZA 09-1580.

${ }^{143}$ Ibid.

${ }^{144}$ Ibid.
} 


\section{ACKNOWLEDGMENTS}

This paper was developed based on her Ph.D. thesis entitled, "Foreign Investment and Sustainable Development: A Critical Analysis from the Sri Lankan Legal Perspective," at the Faculty of Law, Queensland University of Technology, Brisbane, Australia, in 2019.

\section{REFERENCES}

Aid, Christian, Behind The Mask The Real Face of Corporate Social Responsibility (Christian Aid, 2004).

Aswathappa, K, International Business (McGraw Hill Education, 2015).

Birnie, Patricia W, Alan E Boyle' \& Catherine Redgwell, International Law and the Environment (Oxford University Press, 2009).

Bonnitcha, Jonathan \& Robert McCorquodale, "The Concept of 'Due Diligence' in the UN Guiding Principles on Business and Human Rights" (2017) 28:3 European Journal of International Law.

Bottomley, S \& D Kinley, "Corporations and Human Rights" in Commercial Law and Human Rights (Ashgate, 2002).

Chanin, J M, “The Regulatory Grass is Greener: A Comparative Analysis of the Alien Tort Claims Act and European Union's Green Paper on Corporate Social Responsibility" (2005) 12:2 Indiana Journal of Global Legal Studies.

Christian Aid, "Behind the mask: the real face of corporate social responsibility | Eldis," online: <https://www.eldis.org/document/A14 595>.

Conway, Madeleine, "A New Duty of Care? Tort Liability from Voluntary Human Rights Due Diligence in Global Supply Chains” (2015) 40:2 Queen's Law Journal.

Corporations, United Nations Commission on Transnational, "United Nations Commission on Transnational Corporations: Report of the Secretariat on the Outstanding Issues in the Draft Code of Conduct 
on Transnational Corporations" (1984) 23:3 International Legal Materials 602-625.

Dearing, Andrew, Sustainable Innovation: Drivers and Barriers (Geneva: OECD, 2000).

Dubin, Laurence, "Corporate Social Responsibility Clauses in Investment Treaties - Investment Treaty News" (2018) Investment Treaty News, online: <https://www.iisd.org/itn/en/2018/12/21/corporate-socialresponsibility-clauses-in-investment-treaties-laurence-dubin/> .

Dunning, John H \& Sarianna M Lundan, Multinational Enterprises, and the Global Economy (Cheltenham: Edward Elgar, 2008).

Guthrie, J \& L D Parker, "Corporate Social Reporting: A Rebuttal of Legitimacy Theory” (1989) 19:76 Accounting and Business Research $345-352$.

Hart, Jeffrey A \& Joan Edelman Spero, The Politics of International Economic Relations (London: Routledge, 1997).

Hunter, David, James Salzman \& Durwood Zaelke, International Environmental Law and Policy (Thomson Reuters Foundation/ Foundation Press, 2011).

IAWG, Promoting Standards for Responsible Investment in Value Chains, Inter-Agency Working Group (2011).

ICHRP, Beyond Voluntarism: Human Rights and the Developing International Legal Obligations of Companies, International Council on Human Rights Policy (Versoix, 2002).

ILO, Tripartite Declaration of Principles Concerning Multinational Enterprises and Social Policy (Geneva: International Labor Organization, 2017).

Irene Pietropaoli \& Bobbie Sta Maria, BRIEFING: Development for all, or a privileged few? Business and Human Rights in Southeast Asia, by Irene Pietropaoli \& Bobbie Sta Maria (Business and Human Resource Centre, 2017). 
ISO, Contributing to the UN Sustainable Development Goals with ISO Standards (Geneva: International Organization for Standardization, 2018).

Joseph, Sarah Louise, "An Overview of the Human Rights Accountability of Multinational Enterprises" in Liability of Multinational Corporations Under International Law (Kluwer Law International, 2001).

Kolmar, Mark, Asset Owner Strategy Guide: How to Craft an Investment Strategy (PRI, 2018).

Leonard, H Jaffrey, "Multinational Corporations and Politics in Developing Countries" (1980) 32:3 World Policy.

Mares, Radu, "A Gap in the Corporate Responsibility to Respect Human Rights” (2010) 36:3 Monash University Law Review.

Martin, A D \& C Deegan, "The Legitimising Effect of Social and Environmental Disclosures - A Theoretical Foundation" (2002) 15:3 Accounting, Auditing, and Accountability Journal.

Martin, A D \& D J Hadley, "Corporate environmental non-reporting - a UK FTSE 350 perspective” (2008) 17:4 Business Strategy and Environment.

Matin-Ortega, Olga, "Human Rights Due Diligence for Corporations: From Voluntary Standards to Hard Law at Last" (2013) 32:1 Netherlands Quarterly of Human Rights.

McCorquodale, Robert, "Waving Not Drowning: Kiobel Outside the United States" (2013) 107:4 The American Journal of International Law.

Meyer, William H, "Human Rights and MNCs: Theory versus Quantitative Analysis" (1996) 18:2 Human Rights Quarterly 368397.

Miretski, Pini P \& Sascha-Dominik Bachmann, "The UN 'Norms on the Responsibility of Transnational Corporations and Other Business Enterprises with Regard to Human Rights': A Requiem"' (2012) 17:1 Deakin Law Review. 
Murphy, Sean D, "Taking Multinational Corporate Codes of Conduct to the Next Level" (2005) 43:2 Columbia Journal of Transnational Law $1-25$.

OECD, Annual Report on the OECD Guidelines for Multinational Enterprises 2017 (2018).

OECD OECD Guidelines for Multinational Enterprises (Paris: OECD Publishing, 2008).

OECD, OECD Due Diligence Guidance for Responsible Business Conduct (OECD, 2018).

Pendleton, Andrew, "The Real Face of Corporate Social Responsibility" (2004) 14:3 Consumer Policy Review.

Prislan, Vid \& Ruben Zandvliet, "Mainstreaming Sustainable Development into International Investment Agreements: What Role for Labour Provisions?" in International Investment Law and Development: Bridging the Gap (Edward Elgar Publishing, 2015).

Richter, Judith, Codes in Context: TNC Regulation in an Era of Dialogues and Partnership (2002).

Rikhardsson, P, R J A Andersen \& H Bang, "Sustainability Reporting on the Internet: A Study of the Global Fortune 500" (2002) 40 Greener Management International 57-75.

Rubin, Seymour J, "Transnational Corporations and International Codes of Conduct: A Study of the Relationship Between International Legal Cooperation and Economic Development" (1995) 10:4 American University International Law Review.

Shao, Yanmin, "Does FDI Affect Carbon Intensity? New Evidence From Dynamic Panel Analysis" (2018) 10:1 International Journal of Climate Change Strategies and Management 27-42.

Sornarajah, M. The Settlement of Foreign Investment Disputes (Kluwer Law International, 2000).

Sornarajah, M, The International Law on Foreign Investment (Cambridge University Press, 2021). 
Stiglitz, Joseph E, "Multinational Corporations: Balancing Rights and Responsibilities" (2017) 101 Proceedings of the ASIL Annual Meeting.

UNCTC, Commission on Transnational Corporations: Report on the Special Session E/1983/17/Rev.1 (New York, 1983).

United Nations, Guide To The Global Compact: A Practical Understanding of the Vision and Nine Principles (United Nations, 2003).

United Nations, The Guiding Principles on Business and Human Rights: Implementing the United Nations "Protect, Respect and Remedy" Framework (Geneva: Publishing Service, 2011).

UNCTAD, Making FDI Work for Sustainable Development (Geneva: UNCTAD, 2004).

UNCTAD, World Investment Report 2017: Investment and The Digital Economy (Geneva, 2017).

Weissbrodt, David \& Muria Kruger, "Norms on the Responsibilities of Transnational Corporations and Other Business Enterprises with Regard to Human Rights" (2003) 97:4 American Journal of International Law.

World Bank, World Development Report 2017: Governance and The Law, (Washington, 2017).

World Bank Group, Global Investment Competitiveness Report 2017/2018: Foreign Investor Perspectives and Policy Implications (World Bank Group, 2018). 